\title{
Legal vacuum of broadcasting supervision on digital social media
}

\author{
Y. Marpi*, Erlangga \& R.G. Meru \\ University of Jakarta, Jakarta, Indonesia \\ W. Mahardi \\ University of Indonesia, Jakarta, Indonesia \\ U. Meylina \\ University of Lampung, Lampung, Indonesia
}

\begin{abstract}
The study of the monitoring analysis of digital media content broadcasting is deemed necessary as an aspect of legal accountability for digital media content broadcasting based on Law Number 32 of 2002 concerning Broadcasting to ensure legal certainty equal to conventional television broadcasting. With normative juridical research on digital content broadcasting, so far there have been no legal rules that regulate and supervise the implementation and broadcasting so that the emergence of a legal vacuum. Digital conventional broadcasters must comply with the provisions of the broadcasting law to have legal responsibility for broadcasting digital content on YouTube, Net-flix, Instagram, Facebook. The results show that the content created in digital media broadcasting has no legal regulation and provision to obey rules of broadcasting law in the future will have an impact on concerns about the emergence of content that is contrary to the 1945 Constitution and Pancasila.
\end{abstract}

Keywords: legal vacuum, broadcasting, digital media

\section{INTRODUCTION}

Television broadcast digitization policy should be viewed as an opportunity to expand and expand the range of various types of broadcasting services for listeners and viewers. This is because so far, the reality of broadcasting carried out by television providers has not reached the audience or listeners evenly with various types of services. Media broadcasting media content YouTube, Netflix, Instagram, Facebook in disseminating the content of broadcast frequencies using the internet. The use of the Internet is based on the amount of space and bandwidth vibration that can only be used by one party, such as concurrent use of space and the amount of vibration and the same width, or share that would interfere (Wicaksono 2020).

Telecommunication frequencies are used to carry or distribute information so that frequency regulation includes: the allocation of frequency bands and designation. Therefore, since the establishment of an international forum in the field of telecommunications, broadcasting in the aspects of technical operations, handled by the ITU so that according to international regulations, broadcasters are part of telecommunications.

In the study of communication, frequency is categorized as public property or public domain. There are three definitions of the frequency status as public domain, namely: (1) public objects, (2) public property, (3) public sphere. At the technical level, broadcast digitization is a term used to describe the process of changing media formats from analog to digital (Mawanda \& Muhshi 2019). Technically, digitization is the process of changing all forms of information (numbers, words,

${ }^{*}$ Corresponding Author 
images, sound, data, and motion) encoded into bits (binary digits) so that data manipulation and transformation are possible including multiplication, subtraction, and addition (Abdullah 1992). The perfection of digital television is expected to ensure the broadcasting industry with an increasingly diverse market. If the previous time broadcast receivers only through broadcasting media content YouTube, Netflix, Instagram, Facebook now with the invention of tablets and smartphones (Adi 2012).

Definition television broadcasting is a communication medium that can be heard by the masses who convey information and ideas openly in public in the form of pictures, video, and sound, which contains a continuous and regular program. While television broadcasting is a communication medium that can be seen and heard by the masses or the general public, which conveys information and ideas openly or privately, which contains a continuous and regular program (Saputra 2020).

Judging from the potential of the technology, broadcasting via optical cable is superior to others, because this technology allows for interactive menus. However, if today the subject of heated discussion is terrestrial broadcasting, it is not independent of the nature of these frequencies that are public domain. The public sphere is the reason for their rules and policies to safeguard the public interest in addition to its power in shaping the information society Law Number 32 of 2002 on Broadcasting (Bachtiar 2015). This public nature also prevents the broadcast migration process from running smoothly according to the predetermined stages. The public still does not understand the implementation of digital broadcasting (Indonesia 2002).

The information socialized contains more about the advantages of digital broadcasting image quality (Lev 2013). Meanwhile, the understanding of this is not well understood. This situation is often exploited by the seller of the television to spend the stock sales of analog TV (Marzuki 2016). While sufficient information on the specifications of televisions compatible with digital broadcasting technology seems deliberately not provided by the seller of the television. Step process of digitalization of television broadcasting in Indonesia is visible in the Regulation of the Minister of Communication and Information Technology Number 2/P/Kominfo/8/2008 on Field Trial Implementation of Digital Television Broadcast (Hakim 2010). Television is only watched without a variety of other activities. Second Hybrid TV namely broadcast simultaneously between TV and the internet. The Internet is expected to be able to bridge with TV.

People's behavior in consuming TV and the internet is different. They consume the internet for more than six hours. While watching TV is only about an hour. Hybrid broadcasting is done to fulfill this kind of behavior so that those who are playing the internet can also watch TV activities. This broadcasting will be able to adapt the various devices in the community to receive TV broadcasts, including mobile TV. Currently, it seems that the Indonesian people are still on Traditional TV. Television as a medium in broadcasting plays a very vital role in contemporary interactions which have urgently been made in a package of regulations. This is because the media have their unique and strong technical capabilities and their compelling contents are the most effective means of information diffusion ever created by humans (Arliman 2017).

The mass media not only crosses geographical boundaries, but also class, racial, cultural, political, educational, and gender boundaries. To distribute the various types of information that are conveyed regularly, both in the form of entertainment that instills and refreshes certain points of view and ways of understanding (Shabana 2018). Hence, the mass media can articulate an ideological synthesis that promotes certain perspectives by excluding others by linking ideological change and sources of authority and helps construct and regulate social reality by structuring some of the most prevalent and most important experiences of their audiences. The era of digital broadcasting has resulted in television broadcasting services that have a function in each frequency channel served by only one television industry.

\section{METHODS}

This study uses an exploratory research method with an inductive normative juridical approach, namely an approach by drawing general conclusions from real facts in the field. Inductive is a 
way of thinking, in which general conclusions are drawn from various individual cases. Inductive drawing conclusions begins with compiling general statements. This research was conducted to see the aspects related to the legal vacuum in managing audio-visual recording media broadcasting media content programs YouTube, Netflix, Instagram, Facebook (Wahyuni 2006).

In the process of qualitative analysis, according to Miles \& Huberman, namely: data collection, data reduction, data presentation.

\section{RESULTS AND DISCUSSION}

\subsection{Efforts to overcome the legal void of social media broadcasting}

Regulations are needed to control access to a limited spectrum and ensure that the spectrum is used by people or organizations that are responsible for the public interest. The presence of the internet creates a new paradigm regarding the process of delivering information and messages. In terms of distribution, there are differences in distribution processes that occur due to the shift in conventional media such as television or radio to the new internet media (Abdullah 2020). In conventional television and radio media, content is distributed using terrestrial or cable/satellite waves in one direction, from television stations to the wider community.

By reviewing Law Number 32 of 2002, it turns out that there is no Indonesian Broadcasting Commission (KPI) authority to supervise content on streaming platforms such as Netflix, YouTube, and so on, considering that this media is a digital media that is new and has not many enthusiasts before the formation of the latest broadcast law. So that the first step that will be taken by KPI is KPI plans to revise the Law on Broadcasting (Budiman 2015). This supervision is carried out so that content on digital media is not only worth watching, but also educational and has a moral message that is in accordance with the noble values of Pancasila. Another reason for the purpose of this KPI is because considering that most people have switched from conventional television and radio media and are more inclined to access media or content on streaming platforms.

In conventional television and radio media, content is distributed using terrestrial or cable/satellite waves in one direction, from television stations to the wider community. The emergence of DMBs has influenced future generations of network environments. This socio-technical perspective is based on the theory of social construction which sees technology issues as both technical and social problems (Rachmat 2017).

According to Article 36 of Law Number 32 of 2002, the scope of content that is prohibited and under surveillance is content that is slanderous, incitement, misleading and/or lies, elements of violence, obscenity, gambling, narcotics and drug abuse. Contrasting ethnicity, religion, race and between groups, ridiculing, degrading, harassing, ignoring religious values, Indonesian human dignity, or damaging international relations (Wardah 2014).

To completely eliminate influences, it is not in the sense of free to express opinions, but free of capital, careerism, and bourgeois anarchist individualism. The positive impact of social media broadcasting, such as broadcasting media content on YouTube, Netflix, Instagram, Facebook, is that people can get information quickly, so that the same information message can be received simultaneously and for a moment, communication through the media is considered effective in some conditions.

\subsection{Indonesian broadcasting commission authority in restricting broadcasting of media content on YouTube, Netflix, Instagram, Facebook}

As mandated by Law Number 32 of 2002, KPI was given the authority as well as the function to compile and supervise various regulations related to broadcasting by synergizing broadcasting institutions with the government and society. This arrangement also covers the entire process of broadcasting activities, starting from the establishment stage, operationalization, accountability, and evaluation. 
One of the KPIs powers under the Broadcasting Law is to oversee the implementation of broadcasting regulations and code of conduct and broadcast program standards. The aforementioned limitations regarding the objects of the authority of the KPI have been regulated quite clearly in Article 13 of Law Number 32 of 2002. Thus, the authority of KPI as a broadcasting operator is limited to radio and television content, as well as broadcasting institutions (Prabowo 2012). In other words, the KPI is not authorized to supervise new digital media, including You tube, Facebook, Instagram, Netflix, and so on. The issue that there will be an expansion of supervision over the authority of KPI to supervise content in new media, KPI intends to seek regulations that will later become guidelines to add to the object of monitoring digital content from media that has recently been loved by many people such as YouTube, Facebook, Netflix, and the media of a kind.

As referred to by the definition of Broadcasting in Article 6 of Law Number 32 of 2002 concerning Broadcasting, in which broadcasting which is received by the public simultaneously, simultaneously and freely, has a major influence in the formation of opinions, patterns of thought, attitudes and behavior of audiences, so with such an impact, broadcasting organizers should take part in maintaining moral values, morals, culture, personality and national unity based on Pancasila. In line with the task of the KPI institution in supervising content disseminated in the public both on television and radio, as well as content in new digital media, including: YouTube, Netflix, Facebook or similar media provided that they will revise the Law on Broadcasting in terms of KPIs authority to supervise. broadcast content in new digital media. With the discourse of adding KPIs supervisory authority to new media, one of which is Netflix media, the author thinks that this is not urgent to do (Azis 2019).

\section{CONCLUSIONS}

The emptiness or emptiness of legal science can occur due to various causes besides our tradition of legal discovery which is based on the tradition of jurisprudence which is not included in the flow of legal science so that its development is very slow also due to the rapid progress and growth of community dynamics that cannot be balanced by filling or adding laws. with the tradition jurisprudence that is currently happening. Digital broadcasting technology is a new era in terms of production, distribution, and business. From the production aspect, the supporting equipment for this technology is digital-based. Broadcasters that currently use analog technology, inevitably have to invest in digital equipment. This aspect does not seem to be a big problem in the broadcasting world in Indonesia, because of broadcasting media content on YouTube, Netflix, Instagram, Facebook. The second aspect of the distribution problem relates to the receiving device. Currently, the public does not understand about digital broadcast receiving devices. So that when shopping for a television, this technological aspect is not a consideration. These three business problems. The digital television business model at the center of its industry is the multiplexer implementer. To build a multiplexer requires a large amount of capital. Meanwhile the broadcasters must hire the owner of the multiplexer. For large broadcasters like it is today, investing in digital TV is hardly a problem. From the research activities that have been carried out, the conclusions that the researchers can convey the creative elements of production in the Pesbukers program in planning on paper are made not to violate broadcasting ethics. The presentation of shows in the form of dialogue fragments from the players with obscene or insulting words is a form of spontaneity/not found in the script or production briefing before the program activities take place, this is a one-sided improvisation from the players while on stage, the other supporters of the event, namely the studio audience who can interact directly with both verbal context (speech) and attitudes and other players as opposed to dialogue are also able to foster spontaneous attitudes and speech to players who are in dialogue, resulting in a momentary dialogue outside the script.

\section{REFERENCES}

Abdullah, A. 2020. The form of broadcasting digitalization policy in Indonesia. Jurnal Aristo 08(1): 76-96. Abdullah, R. 1992. Hukum acara peradilan tata usaha negara. Jakarta: Raja Grafindo Persada. 
Adi, R. 2012. Sosiologi hukum: Kajian hukum secara sosiologis. Jakarta: Yayasan Obor Indonesia.

Arliman, L. 2017. Komisi Penyiaran Indonesia sebagai state auxiliary bodies.Veritas et Justitia 3(1): $138-162$.

Azis, A.P.A. 2019. Kekosongan hukum acara dan krisis access to justice dalam kasus-kasus pemberhentian kepala daerah/wakil kepala. Jurnal Hukum \& Pembangunan 49(1): 1-43.

Bachtiar. 2015. Problematika implementasi putusan Mahkamah Konstitusi pada pengujian UU terhadap UUD. Jakarta: Penebar Swadaya Grup.

Budiman, A. 2015. Model pengelolaan digitalisasi penyiaran di Indonesia (Model of digitalization of broadcasting in Indonesia). Politica 6(2): 107-122.

Hakim, L. 2010. Kedudukan Hukum Komisi Negara di Indonesia. Malang: Setara Press.

Lev, D.S. 2013. Politik dan hukum di Indonesia: Kesinambungan dan perubahan. Jakarta: LP3ES.

Marzuki, P.M. 2016. Penelitian hukum. Jakarta: Kencana.

Mawanda, M.K. \& Muhshi, A. 2019. Perlindungan hukum mitra ojek daring di Indonesia. Lentera Hukum 6(1): 33-52.

Prabowo, A. 2012. Era penyiaran digital: Pengembangan atau pemberangusan tv lokal dan tv komunitas Jurnal Komunikasi 1(4): 301-314.

Rachmat, I. 2017. The use of social media youtube as audio-visual record document management: exploratory study of application the guidelines behavior broadcasting, Standard of Broadcast Programs (P3 and SPS) ANTV on Pesbukers Television Program. Record and Library Journal 3(9): 38-49.

Republik of Indonesia. 2002. Undang-undang Nomor 32 Tahun 2002 tentang Penyiaran.

Saputra, A. 2020. Seret YouTube-Netflix, ini isi gugatan RCTI soal UU Penyiaran, detikNews. Retrieved from news.detik.com/berita/d-5149091/seret-youtube-netflix-ini-isi-gugatan-rcti-soal-uu-penyiaran.

Shabana, A. 2018. Sistem Stasiun Jaringan (SSJ): Implementasi dan kendala yang dihadapi. Jurnal Perpektif 2(2).

Wahyuni, H.I. 2006. Ekonomi politik kebijakan penyiaran Indonesia. Jurnal Kebijakan dan Administrasi Publik 2(10): 149-168.

Wardah. 2014. Hak konsumen dalam penyiaran televisi. Kanun Jurnal Ilmu Hukum 6(4): 525-537.

Wicaksono, A. 2020. UU Penyiaran tak berlaku ke Netflix-YouTube, RCTI gugat ke MK, CNN Indonesia. Retrieved from: https://www.cnnindonesia.com/nasional/20200529181526-12-508073/uu-penyiaran-takberlaku-ke-netflix-youtube-rcti-gugat-ke-mk. 